\title{
The Effect of Domestic Currency Devaluation on Trade Balance in Ethiopia
}

\author{
Weldeslasie Teklencheal Berhe \\ Ethiopian Police University college, student admission and registrar office \\ Kidanemariam Gidey Gebrehiwot \\ Ethiopian Civil Service University; College of Finance, Management and Development; department of \\ development Economics and Management
}

\begin{abstract}
The prime objective of the study was to investigate the effect of domestic currency devaluation on trade balance in Ethiopian over the period 1974-2016. To address the objective, ARDL and Error Correction Model were applied. The ARDL bound test result shown that There is a long run relationship between real effective exchange rate, real domestic income and lending interest rate .Specifically, real effective exchange rate, real domestic income and lending interest rate have a significant and positive effect on trade balance; whereas money supply and government expenditure deteriorated trade balance while deposit interest rate was insignificant in the long run. This clearly shows that both elasticity and absorption approaches improved the trade balance but monetary measures have deteriorated it. Hence; the government should take follow contractionary monetary policy and absorption approach through productivity improvement, diversification of export sectors and expansion of import computing industries to overcome trade deficit.
\end{abstract}

Keywords: Ethiopia, Trade Balance, Currency Devaluation, ARDL Bound test.

DOI: $10.7176 /$ RJFA/11-1-03

Publication date: January $31^{\text {st }} 2020$

\section{Introduction}

Our world faces insufficient match between limited resource and unlimited human wants. To solve this mismatch, many countries are trading their production in international market by determining their currency value with respect to US dollar. This international trade critically affected by exchange rate system and developing countries are vulnerable to this system (Kibret, 1994).

Issue of currency devaluation or appreciation levels and their relationship with economic variables have a great deal of discussion since mid-2000s, while global imbalances started to widen (Hacioglu and Dincer, 2013). Because import and export orders are processed several months in advance the devaluation of currency is mostly synonymous with deterioration of trade balance in the short run (Paul and Maurice, 2012). The economic concepts of J-curve and depreciation of currency closely related which worsen the trade balance in short run since volume of the imports remains stable but in the long run there is increase in exports and reduction in imports (Magee, 1973). The exchange rate affects trade balance through its effects on competitiveness; the appreciation of domestic currency increases cost of production and the country decreases its competitiveness in the global market and this leads to trade deficit (Morck et al., 2000). During the three successive regimes in Ethiopia pre 1974, totalitarian Derg period and post 1991 shown that the country's external trade policies were free trade, controlled trade policies and once again back to free trade policy and the exchange rate was regarded as fixed in pre 1990 and post 1990 was floated. Under the structural adjustment program with the support of international monetary fund and World Bank during 1992/93 the Ethiopian birr was devaluated from 2.07 birr to 5 birr per US dollar and its devaluation was continuously reached about 27.41 in 2017 with objective of balancing external sector in general and improving account balance and boost exports specifically and to stay competitive on price (NBE, 2018).

\section{Literature Review and Problem Statement}

The economic reason for currency devaluation is for contractionary effects of devaluation on aggregate demand and to increases the price of imports relative to domestic goods and lowering imports and stimulating the demand for exports. As a result of currency devaluation domestic price level will go up and this price level has also two consequences. First, it reduces private spending and aggregate demand. Second, it also provokes the redistribution of income because it shifts income from wage earners to profit recipients (Setzer, 2006).

Developing countries' economy was suffered to various economic problems like current account deficit, declining foreign currency reserve, high inflation at home market. To handle these problems some countries impressed to stabilization and Structural Adjustment Program (SAP) with support of IMF and World Bank (Edwards and Savastano, 1999).

Ethiopia's export is characterized by high commodity and geographic concentration, susceptibility to external shocks, dependence on agricultural export that in turn depends on vagaries of nature, high price and low-income 
elasticity of demand, and low supply response. On the other hand, imports intrinsically are highly price inelastic which are either necessities in production or consumption or very strategic commodity and are invariably required by the country. Therefore, the gap between export-import leads to a persistent deficit trade balance in the country. The existence of persistent trade deficit is fundamentally structural in nature in Ethiopia, because imports are essential that they are price inelastic and cannot simply be discouraged or easily substituted while exports are highly concentrated on agricultural primary commodities that are very sensitive to whether condition and price shocks (Lencho, 2013).

Since Ethiopia depends on export of agricultural product and import of capital goods; devaluation deteriorates trade balance even if increasing currency devaluation was expected to encourage the export sector and still the country's trade balance shows continuous trade deficit (MOFED, 2010). This case leads to ambiguity for the currency devaluation policy measurement. Whatever the case is, Ethiopian government still used currency devaluation approach from among the absorption and monetary approaches as macroeconomic policy to improve trade balance and many researchers were dealt about it and the ambiguity for the currency devaluation is continued.

There are also arguments among researchers about the effects of currency devaluation on trade balance of Ethiopia, such studies conducted by Kibre (1994), Asmamaw (2008), Befirdu (2014) and Fassil (2017) shown that birr devaluation improved Ethiopian trade balance but in other round studies conducted by Kidane (1999) and Alemu(2008) indicated that birr devaluation deteriorated trade balance since the country's rate of import is much higher than the rate of export.

Studies that have done on the relationship of currency devaluation and trade balanc; such as effect of exchange rate movement on trade balance in Ethiopia (Lencho, 2013) and trade balance and exchange rate (Gebeyehu, 2014) were studied the effects of currency devaluation on trade balance using Johnson's Co-integration technique.

However; the Johnson's Co-integration technique is one of the widely used methods of time series analysis, its outcome could not be reliable for small sample size (Pesaran and Shin, 1997; Narayan, 2005) relatively, the Autoregressive distributed lag method of co-integration has more advantage over the Johnsons method (Pesaran and Shin, 1997; Pesaran and Shin, 1999; Pesaran, Shin, and Smith, 2001; Harris and Sollis, 2003; Narayan, 2005 and Chaudhry, 2006). Hence this paper has used Autoregressive distributed lag method to provide valid empirical evidence and to avoid the problem of biasness that arises from small sample size.

Therefore, these arguments, government measurement of currency devaluation to improve trade balance and the methodological gaps motivated the researcher for the problem statement of this study that considered investigating whether currency devaluation improves trade balance based on empirical analysis of trade balance responsiveness for birr devaluation in short run and long run. The objective of this research was to empirically investigate the effect of domestic currency devaluation on trade balance in Ethiopia in both in the short run and long run3. Materials and Methods

According to Magazzino et al (2012), there are various aspects to time series analysis but the most common is to fully exploit the dynamic structure in the data which extracts as much information as possible from the past history of the series. The key purpose of time series analysis is to capture and examine the dynamics of the data. In the context of time series regression, the idea that historical relationships can be generalized to the future is formalized by the concept of stationarity (Binh, 2013).

According to Gujarati (2004), the so-called stationary stochastic process means mean and variance are constant over time and the value of the covariance between the two periods depends only on the distance or gap or lag between the two time periods and not on the actual time at which the covariance is computed.

The concept of co integration was first introduced by Granger (1981) and elaborated further by Engle and Granger (1987), Engle and Yoo (1987), Phillips and Ouliaris (1990), Stock and Watson (1988), Phillips (1986 and 1987), and Johansen $(1988,1991$, and 1995). It is known that trended time series can potentially create major problems in empirical econometrics due to spurious regressions. One way of resolving this is to difference the series successively until stationary is achieved and then use the stationary series for regression analysis.

\subsection{Time series models /ARDL, VECM and VAR}

In a time series data type there are different models which mainly categorize based on the variables order stationarity and existence of co integration. If a group of time series variables are individually integrated of the same order and if at least one linear combination of these variables is stationary, then the variables are said to be co-integrated (Harris, 1999 and Enders, 2004). This tells us a long-run relationship between the variables. Vector auto regression (VAR) was introduced by Sims (1980) as a technique that could be used by macroeconomists to characterize the joint dynamic behavior of a collection of variables without requiring strong restrictions of the kind needed to identify underlying structural parameters. It has become a prevalent method of time-series modeling.

Both Engle-Granger Approach and Johansen co integration techniques used tests of co integration variables of the same order of staionarity and large sample size. Pesaran and Shin (1997, 1999, and 2001) have developed a new ARDL model which has more advantages than both Engle-Granger Approach and Johansen co integration techniques and this approach can solve the problems which created during small sample size and variables of 
different order of co integration I(0) and I(1). The ARDL co integration test uses bound tests rather than Johansen co integration test. ARDL procedure provides statistically significant result in small samples that means, it avoids the problem of biasness that arises from small sample size (Chaudhry, 2016).

\subsection{Model Specification}

In an open economy financial markets different scholar have designed different conceptual frameworks that incorporate currency devaluation as one of the determinant factor of trade balance of a given country. Among those scholars, Fassil (2017) and, Abebe (2014) had accommodated birr devaluation as an independent factor of trade balance of Ethiopia in their empirical analysis as well as money supply, real gross domestic product and interest rates also used as determinant factors for trade balance. These researchers had employed log linear transformation model as their framework specification to analyze relationship between the dependent and independent variables.

The overall objective of this study was to test the effect of currency devaluation on the trade balance of Ethiopia for the period 1974-2016 using Autoregressive Distributed Lags (ARDL) because of small sample size and variables are co integrated of I (0) and I (1). Therefore, ARDL is advantageous over the Engle-Granger and Vector Error Correction Models (Pesaran and Shin, 1997, 1999, and 2001). Since the objective of this study was consolidated about the trade balance improvement approaches such that elasticity, absorption and monetary approaches the model was derived based on these three approaches in line with methodology at hand (Piontkivsky, 1999):

Using the synthesis equations of the trade balance approaches (the absorption, elasticity and monetary approaches) based on the international fiancé and by splitting interest rate in to lending and deposit interest rates the specified model for this study is:

$$
\mathrm{TBt}=\beta 0+\beta 1 \mathrm{REERt}+\beta 2 \mathrm{Yt}+\beta 3 \mathrm{Gt}+\beta 4 \mathrm{MSt}+\beta 5 \mathrm{RLt}+\beta 6 \mathrm{RDt}
$$

Since the study focused on responsiveness of trade on the change of domestic currency value they shall be transformed in to logarithm in order to deal the elasticity issues of currency devaluation on Ethiopian trade balance over the period 1974 to 2016 . Note that, TB is negative value but it was considered as positive, only for the purpose of logarithm and in the interpretation case the negative sign was granted. Therefore;

$$
\mathrm{LTBt}=\beta 0+\beta 1 \mathrm{LREERt}+\beta 2 \mathrm{LYt}+\beta 3 \mathrm{LGt}+\beta 4 \mathrm{LMSt}+\beta 5 \mathrm{LRLt}+\beta 6 \mathrm{LRDt}+\mathrm{Ut}
$$

Where, $\quad \mathrm{LTBt}=$ Logarithm of trade balance at time $\mathrm{t}$.

LREER $\mathrm{t}=$ Logarithm of real effective exchange rate at time $\mathrm{t}$.

$\mathrm{LY} t=$ Logarithm of domestic real income at time $\mathrm{t}$.

$\mathrm{LG} t=$ Logarithm of government expenditure at time $\mathrm{t}$.

LMSt $=$ Logarithm of money supply at time $\mathrm{t}$.

LRL $t=$ Logarithm of lending interest rate at time $t$.

LRD $\mathrm{t}=$ Logarithm of deposit interest rate at time $\mathrm{t}$.

$\mathrm{Ut}=$ The random error at time $\mathrm{t}$.

The regression of the trade balance as it appears in Equation 8 has derived from the perspective of three approaches trade balance improvement (elasticity, absorption and monetary). The elasticity approach focuses on real effective exchange rate (REERt) as the determinants of the trade balance and thus the relevant coefficient is $\beta 1$. The monetary approach assumes money supply (MSt) as the determinants of the trade balance and hence the relevant coefficient is $\beta 4$ and absorption approach considers domestic real income (Yt) as key determinants of the trade balance and hence the relevant coefficient is $\beta 2$. In this study of effect of currency devaluation on trade balance the variable REERt is targeted and its coefficient $\beta 1$ is our key interest and expected signs of $\beta 2$ and $\beta 4$ is negative whereas $\beta 1$ is undetermined (Salvatore, 2001).

\subsection{Method of Data Analysis}

The descriptive statistics and econometric methods have employed throughout this study to discuss and analyze the time series data. Initially examining the characteristics (stationarity and long run relationship behaviors of variables) of the time series data is mandatory before any model estimation. Auto Regressive Distributed Lag (ARDL) used to examine characteristics of the time series data rather than Vector Error Correction Model (VECM) /Johnson because in this study the observations are small which is 43 and variables were I (0) and I (1). Before running any time series regression analysis testing variable stationarit is required. Main objective of stationarity test is to get variable which has a constant mean, variance and covariance because regression results from time series data may generate spurious regression if the variables are non-stationary. To check whether long run relationship between all variables exist or not bound test/co-integration has applied and Augmented DickeyFuller(ADF ) was used for test of stationarity or unit root test based on the null hypothesis that a unit root is exist in the time series data(Guajarati, 2004).

ADF tested the unit root both at level and at difference for the variables which included in the model. Data have analyzed using EViews 9 software tool. The econometric methods that investigated effects of independent variables on dependent variable were treated in logarithmic form in order to minimize inflationary effect and to 
Table 4.2: Optimum lag selection criteria using AIC, SIC and HQIC.

\begin{tabular}{lllccc}
\hline \hline Number of lags & AIC & SIC & HQIC & Selected Optimum lag \\
\hline \hline Lag 1 & -2.073 & -1.742 & -1.952 & & \\
Lag 2 & -2.117 & -1.615 & -1.934 & & \\
Lag 3 & -2.389 & -1.544 & -2.084 & & \\
Lag 4 & $-6.187^{*}$ & $-4.737^{*}$ & -5.667 & & \\
Lag 5 & -6.027 & -4.231 & -6.157 & & \\
Lag 6 & -6.154 & -4.526 & -6.891 & & \\
Lag 7 & -6.002 & -3.987 & $-7.301^{*}$ & & \\
Lag 8 & -5.689 & -3.456 & -7.021 & & \\
\hline \hline
\end{tabular}

Note: More IC is granted and the low the value of IC is the best the model is in that lag number. Akaike info criterion (AIC), Schwarz info criterion(SIC) and Hanan-Quinn info criterion (HQIC)

Therefore the optimum lag length for the ARDL is lag 4 in which values of AIC and SIC are lowest at lag 4 while value of HQIC is lowest at lag 7 but both $\mathrm{AIC}$ and SIC are granted than HQIC alone and it obliged to accept this lag due to the principle stated.

\subsection{Long run ARDL bounds test for co-integration}

Based on the specified optimum lag length the ARDL bounds test approach of co-integration is applied. In this study Akaike Information Criterion (AIC) and Schwarz Information Criterion (SIC) were taken as a guide and a maximum lag order of 4 was chosen for the conditional ARDL model. Then F-test through the Wald-test (bound test) is performed to check the joint significance of the coefficients. The Wald test is conducted by imposing restrictions on the estimated long-run coefficients of trade balance, real effective exchange rate, real domestic income, government expenditure, money supply, lending interest rate and deposit interest rate. The hypothesis tests defined as:

HO: The given variables have not long run association ship / there is no co integration

$$
\text { HO: } \boldsymbol{\pi}_{1}=\boldsymbol{\pi}_{2}=\boldsymbol{\pi}_{3}=\boldsymbol{\pi}_{4}=\boldsymbol{\pi}_{5}=\boldsymbol{\pi}_{6}=\boldsymbol{\pi}_{7}=\mathbf{0} \text {. }
$$

H1: The given variables have long run association ship / there is co integration

$$
\text { H1: } \pi_{1} \neq \pi_{2} \neq \pi_{3} \neq \pi_{4} \neq \pi_{5} \neq \pi_{6} \neq \pi_{7} \neq 0
$$

To decide whether $\mathrm{H} 0$ reject or fail to reject the computed F-statistic value is compared with the lower bound and upper bound critical values tabulated in Table CI (III) case IV of Pesaran, Shin, and Smith (2001).

\begin{tabular}{|c|c|c|c|c|c|}
\hline \multicolumn{2}{|c|}{ Bounds Test for Co integration analysis } & \multicolumn{4}{|c|}{ Pesaran (2001) critical values for $\mathrm{K}=6$} \\
\hline Description & Value & At $1 \% \mathrm{LS}$ & & At $5 \%$ LS & \\
\hline Included obserbvation & 39 & Lower bound & $3.15 * * *$ & Lower bound & $2.45^{* *}$ \\
\hline Optimum Lag length of the Model & 4 & Upper bound & $4.43 * * *$ & Upper bound & $3.61 * *$ \\
\hline Calculated F-statistic & 8.11 & & & & \\
\hline
\end{tabular}

Table 4.3: ARDL bounds test and Pesaran et al. (2001) lower and upper bound cv

Source: Pesaran, Shin, and Smith (2001) table and own computation (2018)

Note: The *** and ** sign indicates the rejection of the null hypothesis of no long-run relationships exist at $1 \%$ and 5\% significant level respectively. Critical Values are cited from Pesaran et al. (2001) Table and $K=6$ is the number of regressors in ARDL long-run model.

As shown above, table 5 is the combination of two tables of ARDL bounds test and Pesaran et al. (2001) lower and upper bound critical values with an intercept and trend. It depicted that the calculated F statistics 8.11 is higher than the Pesaran, Shin, and Smith (2001) upper bound critical value (4.43) at 1 percent level of significance. This implied that the null hypothesis of no long- run relationships exist is rejected rather than its alternative hypothesis (there is long-run relationship) is accepted based on the Pesaran, Shin, and Smith (2001) critical value at 1 percent level of significance. This concluded that the variables of the ARDL model trade balance, real effective exchange rate, gross domestic product, government expenditure, money supply, lending interest rate and deposit interest rate are moving together in the long-run. Therefore, the ARDL model could be estimated because all these macro variables have a long run association ship.

\subsection{Long-run ARDL model estimation.}

The above table 5 results had shown the existence of a long-run relationship among trade balance, real effective exchange rate, gross domestic product, government expenditure, money supply, lending interest rate and deposit interest rate. After confirming the existence of long-run co-integration among these variables, the estimated longrun relationship between the variables have estimated and the estimated coefficients after normalizing on trade balance have reported in table 4.4 below: 
Table 4.4: Estimated long run coefficients using ARDL $(4,4,3,4,4,4,4)$ (TB is DV)

\begin{tabular}{|c|c|c|c|c|}
\hline Regressors & Coefficinets & Std.Error & t-Statistic & Prob \\
\hline LREER & -0.5288 & 0.1215 & -4.3523 & $0.0428 * *$ \\
\hline LY & -0.6473 & 0.2622 & -2.4687 & $0.0319 * *$ \\
\hline LG & 1.3326 & 0.2291 & 5.8191 & $0.0432 * *$ \\
\hline LMS & 3.5411 & 0.3975 & 8.9093 & $0.0009 * * *$ \\
\hline LRL & -3.6721 & 0.2606 & -14.0886 & $0.0411 * *$ \\
\hline LRD & 3.3267 & 0.2203 & 15.1023 & 0.1025 \\
\hline Constant & -3.4993 & 1.5477 & -2.2609 & 0.0866 \\
\hline Trend & 0.0065 & 0.0236 & 0.2771 & 0.7954 \\
\hline \multicolumn{5}{|c|}{$\begin{array}{l}\text { Long run model is } \mathrm{LTB}=-3.4993-0.5288 \mathrm{LREER}-0.6473 \mathrm{LY}+1.3326 \mathrm{LG}+3.5411 \mathrm{LMS}-3.6721 \mathrm{LRL}+3.3267 \\
\text { LRD }\end{array}$} \\
\hline R-Squared & 0.9518 & Mean of dep. Var & 0.5118 & \\
\hline Adjusted R-Squared & 0.9225 & S.D. of dep. Var & 0.1604 & \\
\hline S.E of Regression & 0.0142 & RSS & 0.00806 & \\
\hline F-Statistic & 142.7082 & Log likelihood & 155.018 & \\
\hline Prob(F-Statistic) & 0.00103 & AIC & -6.1518 & \\
\hline DW-Stat & 2.2237 & SIC & -4.6618 & \\
\hline
\end{tabular}

Source: Own computation using Eviews9 package (2018)

Note: The *** and ** sign indicate the rejection of the null hypothesis at 1\% and $5 \%$ significant level respectively. The coefficient covariance matrix method is Ordinary

The above report (table 6) depicted that the long-run model is statistically significant/adequate at 1 percent level of significance since prob (F-statistic) 0.00103 less than 0.01 and the coefficient of determination (R-squared) is high explaining that about 95.18 percent of variation in the trade balance attributed to variations in the explanatory variables included in the model and there is no evidence of spurious regression since DW-Stat (2.2237) is greater than R-squared (0.9518).

The estimated coefficients of real effective exchange rate and real domestic income have the expected signs but money supply have unexpected sign. This study concentrated on the devaluation theories such that elasticity (coefficient of LREER), absorption (coefficient of LY) and monetary (coefficient of LMS) theories. Therefore, in the trade balance of Ethiopia both elasticity and absorption approaches of trade balance deficit problem solving mechanisms have matched with theoretical signs where as sign of monetary approach has not fitted in Ethiopia as compared with the economic theory. And the estimated coefficients of real effective exchange rate (at 5 percent level), real domestic income (at 5 percent level), government expenditure (at 5 percent level), money supply (at 1 percent level) and lending interest rate (at 5 percent level) are statistically significant while deposit interest rate is not statistically significant.

The trade balance model has specified in a log-linear form under this study, and then coefficient of the dependent variable trade balance can be interpreted as elasticity/percentage change with respect to these explanatory variables. The coefficient of log real effective exchange rate is -0.5288 , this indicates that, in the long run, holding other things constant, a one percent change in real effective exchange rate (appreciation or depreciation of birr against US dollar) brought 0.5288 percent change in trade balance. With understood characteristics of Ethiopian trade deficit behavior the negative sing of LREER indicates that, as birr devaluated by one percent against US dollar the trade balance improved by 0.5288 percent. But, when birr is appreciated by one percent against US dollar the trade balance has been deteriorated by 0.5288 percent.

More than of the real effective exchange rate, real domestic income has significant long run impact on the Ethiopian trade balance. This indicates that, in the long run, holding other things constant, a one percent change in real domestic income brought 0.6473 percent change in trade balance. Under the Ethiopian trade deficit characteristics, the negative sing of LY also indicates that, as Ethiopian real income increased by one percent the trade deficit improved by 0.6473 percent while if it decreased by one percent the trade balance has been deteriorated by 0.6473 percent.

The coefficient of log money supply (LMS) is 3.5411. This indicates that, in the long run, holding other things constant, a one percent change in money supply brought 3.5411 percent change in trade balance. With the Ethiopian trade deficit behavior, the unexpected positive sign of MS indicates that, as money supply increased by one percent trade balance has been deteriorated by 3.5411 percent while if it decreased by one percent the trade deficit improved by 3.5411 percent.

Finding of this study along the long run effect of real effective exchange rate is consistent with the positive effect of birr devaluation on trade balance with respect to the researches made in Ethiopia by Haile (2008), Abebe (2014) and Fassil (2017). But the unexpected sign of the coefficient of money supply (MS) contradicts with monetary approach of trade deficit improvement mechanism. The reason behind being contradicted with the 
monetary approach devaluation theory due to the unexpected sign of money supply may as well as unexpected sign of government expenditure could be due to data and/or valuation problem, but it is difficult to justify the exact reason behind such unexpected signs using this research. Hence, further detailed research should be done to identify the reason behind such unexpected sign of money supply coefficient.

Both government expenditure and lending interest rate have maximum significant effect on trade balance with positive and negative coefficient sign respectively. The positive sign of government expenditure deteriorated the trade balance in the long run when government expenditure increased. While lending interest rate has a negative coefficient sign that improved Ethiopian trade balance at the time percentage increment of lending interest rate. This depicted that, in the long run, holding other things constant, a one percent change in government expenditure and lending interest rate brought 1.3326 and 3.6721 percent change in trade balance respectively.

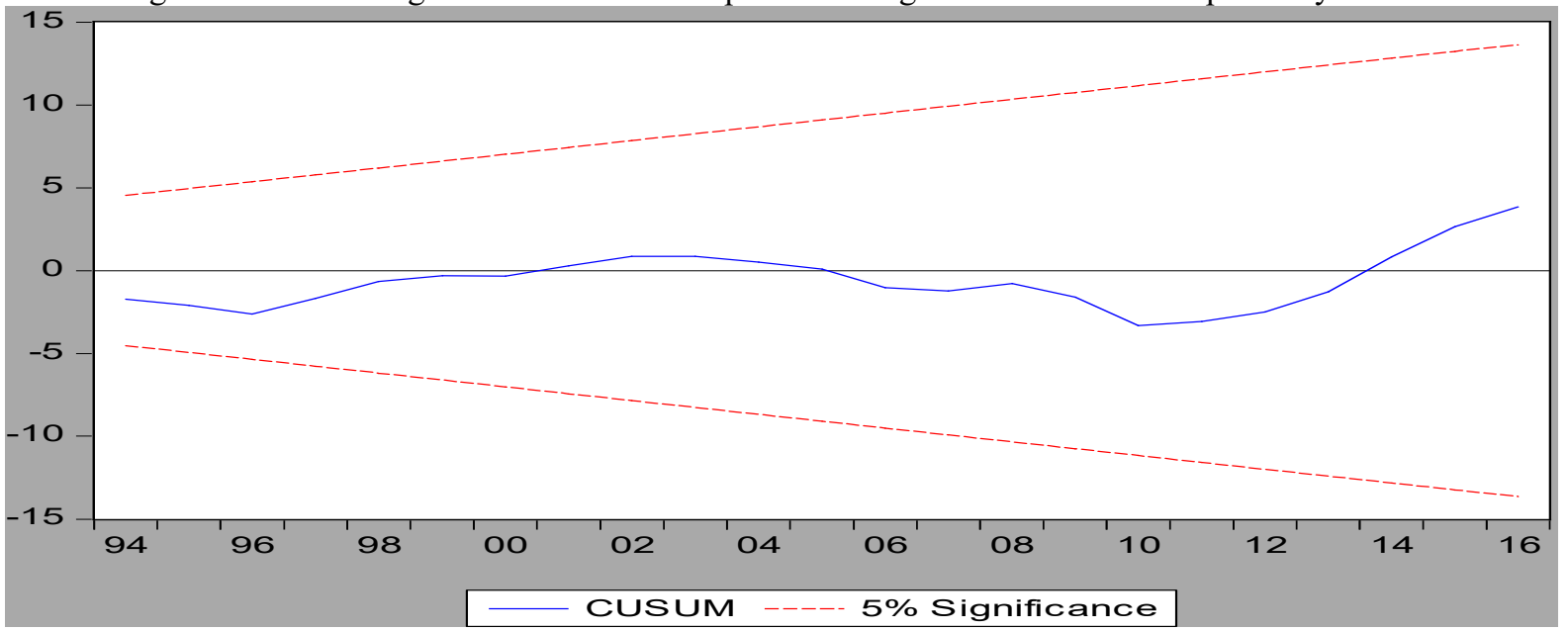

Fig 4.1: Cumulative sum of recursive residuals

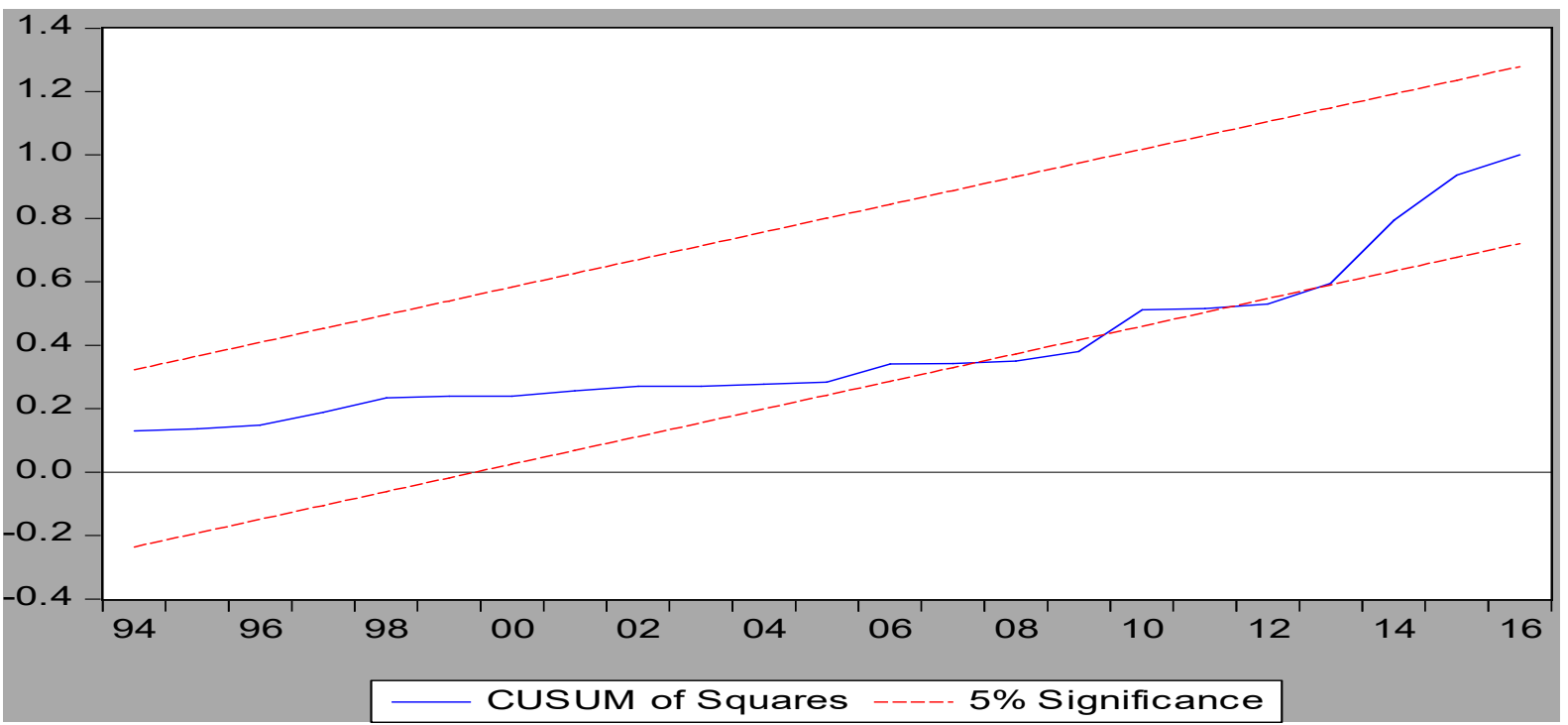

Fig 4.2: Cumulative sum of squares of recursive residuals

Source: Own computation using EViews 9(2018)

Note: The straight lines represent critical bounds at 5\% significance level

To check whether there was a structural breakpoint over the 1974 to 2016 on Ethiopian trade balance due to the exchange rate regimes graphical stability diagnostics tests has been tested by applying the cumulative sum of recursive residuals (CUSUM) and the cumulative sum of squares of recursive residuals (CUSUMSQ) test. The graphical stability tests used not only identifying their significance but also it tells us at what point of time a possible structural break (instability) has occurred. Here, model stability test using cumulative sum of recursive residuals (CUSUM) could be replaced for Chow test structural breakpoint. If the plot of CUSUM / CUSUMSQ statistic moves between the critical bounds/red lines (at 5 percent significance level), then the estimated coefficients or the model/system are/is said to be stable in the long run / short run. The graphical plots of CUSUM and CUSUMSQ have shown below in Fig. 4.1 and Fig. 4.2 respectively.

Figure 4.1 reported that the plot of CUSUM test did not cross the lower and upper red lines critical limits 
which indicated that, the estimate is stable and there is no any structural break in the long run. But CUSUMSQ test reported in Figures 4.2 shown that the graph crosses the lower and upper red lines critical limits around the year 2008 and 2012 and immediately recovered. Therefore, we can conclude the short run estimate is not stable there are structural breakpoints in the year 2008 and 2012. Since our target is the long run estimation the results of the estimated long run model was stable, reliable and efficient.

\subsection{Short run error correction estimation}

Since the long run model coefficients of the trade balance have discussed above; the short run correction model estimation necessary in order to deal the rate of adjustment and to see the responsiveness of trade balance over the currency devaluation in short run. The below report (table 4.5) depicted that the short run model is statistically significant/adequate at 1 percent level of significance since prob (F- statistic) 0.000008 less than 0.01 . The coefficient of determination (R-squared) is high explaining that about 89.92 percent of variation in the trade balance attributed to variations in the explanatory variables included in the model and there is no evidence of spurious regression since DW-Stat (2.1808) is greater than R-Squared (0.8992).

The error correction model coefficient was matched with the hypothesized sign and magnitude. Thus, it estimated -0.27056 which is statistically significant at 1 percent level of significance since p-value 0.0001 is less than 0.01 which indicated that the system is getting adjusted for the long run disequilibrium. Approximately 27.056 percent of the disequilibrium from the previous year's shock converges back to the long-run equilibrium in the current year. This expected sign and significant error correction term is also additional evidence for the existence of a stable long run relationship.

In short run all the explanatory variables were significant because in all independent variables P-value is less than 5 and 1 percent significant level and there is no evidence of spurious regression since DW-Stat (2.180813) is greater than R-squared (0.899160) but in long run deposit interest rate was not significant. There is a significant effect of real effective exchange rate at 1 percent significant level in the first, third and fourth lags and at 5 percent significant level in the second lag on trade balance. This implying that the current real effective exchange rate would still affect the trade balance in the next three and four years as well as the current real domestic income, government expenditure, money supply, lending and deposit interest rates would affect the trade balance for the coming three and four years. A positive sign of real effective exchange rate coefficients in lag 1 and lag 2 implied that depreciation of Ethiopian birr against US dollar deteriorated trade balance of the country however, a negative coefficient in lag 3 and 4 shows improvement in the other way around.

In econometrics, an endogeneity problem occurs when an explanatory variable is correlated with the error term. Endogeneity can arise as a result of measurement error, autoregression with autocorrelated errors, simultaneous causality, omitted selection, and omitted variables. Dependent variable generated within a model and, therefore, a variable whose value is changed (determined) by one of the functional relationships in that model. But in this research model there is no evidence of existence of endogeneity problem based on the result of covariance matrix 
Table 4.5: Error correction representation for $\operatorname{ARDL}$ model $(4, \mathbf{4 , 3}, \mathbf{4 , 4 , 4 , 4 )}(\mathrm{DV}$ is $\underline{\Delta \mathrm{DLTB}})$

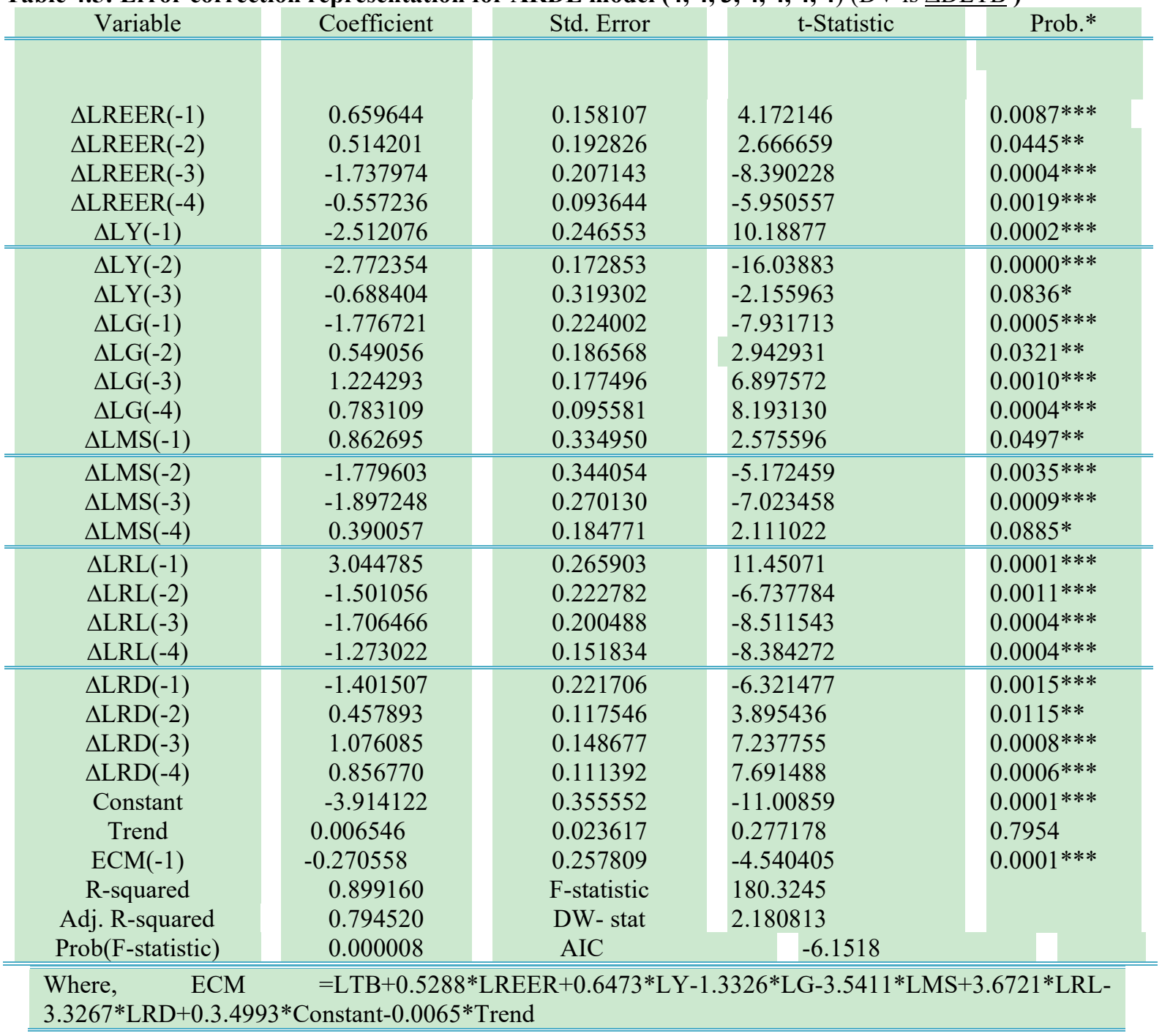

Source:Own computation using Eviews 9(2018)

Note: The *** and ** sign indicates the rejection of the null hypothesis at $1 \%$ and $5 \%$

\section{CONCLUSION AND POLICY IMPLICATION}

\subsection{Conclusion}

The main finding of this paper is that in the long run birr devaluation has improved the trade balance by 0.5288 percent when birr is devaluated by 1 percent against US dollar but in the short run it deteriorated trade balance in which 1 percent birr devaluation brought 0.6597 and 0.5142 percent decreased in trade balance at the immediate two years after devaluation and improves over time.

Real domestic income of the country is a major contributor to improve trade deficit problem rather than birr devaluation in the short and long run; in the short run it brought about 2.5121 and 2.7723 percent in the first two years and in long run about 0.6473 percent improvement of trade balance due to 1 percent increment. While money supply and government expenditure are negatively affected trade balance during the study period which deteriorated by 5.54 and 1.33 percent for 1 percent of a percentage increase respectively as well as percentage increase of lending interest rate has contributed on trade balance improvement.

Therefore, the results revealed that absorption approach is better than elasticity approaches to improve Ethiopian trade balance in both short run and long run, then it could be concluded that birr devaluation approach is less appropriate tool to improve trade balance as compared absorption approach.

In the short run, the coefficient of error correction term is -0.27056 which suggested that the system getting adjusted annually about 27.056 percent towards the long run equilibrium. CUSUM model stability test and Ramsey RESET model specification test revealed that existence of stable long run model and the model was specified as well. This system stability means that there is no any evidence of structural break in the long run due to exchange rate regimes of Dergue and the current governments but in short run there were two breakpoint years (in 2008 and 
2012) but they recovered immediately.

In the short run estimation model real domestic income affects negatively trade balance by 2.5121 percent deterioration for a percentage increase in one period lagged value whereas in two and three period lagged values it affects positively by 2.7723 and 0.6881 percent improvement for a percentage increase respectively. Real effective exchange rate improves trade balance in the long run but in the short run at one and two period lagged values deteriorates by 0.6589 and 0.5142 percent for one percent birr devaluation and starts improvement in the third and fourth period lagged values by 1.7379 and 0.5572 for one percent birr devaluation respectively. Money supply deteriorates trade balance in the long run but in the short run it improves at two and three period lagged values by 1.7796 and 1.8972 percent for a percentage increase respectively.

The finding revealed that trade balance of Ethiopia can be improved in the long run by using birr devaluation as macroeconomic policy measurement but it deteriorated in the short run. This finding is consistent with the findings of Kibret (1994), Asmamaw (2008), Befirdu (2014) and Fassil (2017). Since birr devaluation approach deteriorated trade balance in the short run and as compared to real domestic income it is less appropriate. Therefore, for the Ethiopian trade deficit problem, the best approach is absorption approach by focusing on productivity improvement rather than currency devaluation whereas monetary approach deteriorates trade because the unexpected sign of money supply happened in the ARDL model. There reason behind unexpected sign of money supply may due to e data and/or valuation problem and it needs further detailed research to identify the reason behind of unexpected sign.

Generally from the research findings the research questions concluded that in the short run birr devaluation has negative effect /deteriorated trade balance but in the long run birr devaluation has positive effect/ improved trade balance and birr devaluation is an appropriate tool to improve trade balance but it is less as compared to real domestic income/absorption approach as well as the empirical implications of the trade balance improvement approaches revealed that both elasticity and absorption approaches improved trade balance but monetary approach has deteriorated the trade balance and the policy implications derived from the empirical analysis have been explained below.

\subsection{Policy Implication}

The behavior of trade deficit happening in Ethiopia negatively affects the country's foreign trade and economic growth in general due to shortage of foreign reserve. Therefore, results of this study draw some important policy recommendations. In order to minimize Ethiopian trade deficit it is better to prioritize the absorption approach due to real domestic production level rather than birr devaluation through elasticity approach as long run macroeconomic policy measurement tool. And also lending interest rate increment is recommended as an additional mechanism for trade balance improvement. Government/national bank should take contraction policy measurement on money supply because the result shows money supply deteriorates trade balance.

Therefore, demand side theory/elasticity approach/ of market adjustment suggested to shift in to supply side/absorption approach/ by producing competitive commodities in the world market since in the short run devaluation deteriorate the economy as well as its contribution is lower in the long run as compared to supply side/absorption approach. To boost export performance of Ethiopia and thereby lead to improvement in trade balance the first, is through the rise in export productivity and diversification in the area of agriculture, agroinvestment and mining industries which will improve the country's trade balance and foreign exchange earnings and second, give attention to the import computing industries. This helps to improve Ethiopian trade balance by decreasing dependence on imported goods.

Therefore, government and macroeconomic policy makers have to focus on policies that encourage productivity improvements, diversification of the export sectors and expansion of import computing industries rather than birr devaluation measurement for the long run Ethiopian trade balance improvement.

\section{REFERENCES}

Abebe, B.G., 2014. Exchange rate and trade balance; J curve effect in Ethiopia'. Journal of Economics and Sustainable Development, 5, pp.1-8.

Alemu, A.M. and Jin-sang, L., 2014. Examining the effects of currency depreciation on trade balance in selected Asian economies. International Journal of Global Business, 7(1), p.59.

Asmamaw, H., 2008. The Impact of Devaluation on Trade Balance: The case of Ethiopia (Master's thesis).

Befirdu, E., 2014. Effects of Exchange Rate Devaluation and Its Impact on Trade Balance in Ethiopia.

Binh, P., 2013. Unit Root Tests, Cointegration, ECM, VECM, and Causality Models. Topics in Time Series Econometrics, Article, 110.

Chaudhary, G.M., Hashmi, S.H. and Khan, M.A., 2016. Exchange Rate and Foreign Trade: A Comparative Study of Major South Asian and South-East Asian Countries. Procedia-Social and Behavioral Sciences, 230, pp.8593.

Edwards, S. and Savastano, M.A., 1999. Exchange Rates in Emerging Economies: What do we know? What do we 
need to know? (No. w7228). National bureau of economic research.

Enders, W., 2004. Applied time series econometrics. Hoboken: John Wiley and Sons.

Engle, R.F. and Granger, C.W., 1987. Co-integration and error correction: representation, estimation, and testing. Econometrica: journal of the Econometric Society, pp.251-276.

Engle, R.F. and Yoo, B.S., 1987. Forecasting and testing in co-integrated systems. Journal of econometrics, 35(1), pp.143-159.

Fassil, E., 2017. Birr devaluation and its effect on trade balance of Ethiopia: An empirical analysis. Journal of Economics and International Finance, 9(11), pp.103-119.

Gebeyehu, A.B., 2014. Exchange Rate and Trade Balance; J Curve Effect in Ethiopia. Exchange, 5(24).

Gebeyehu, A.B., 2015. Major Agricultural Trade Volume in Ethiopia: Trade Balance and Exchange Rate Relations a Structural Break Analysis (Using Stability Chow Test, CUSUM and CUSUM Squared Residuals). Journal of Global Economics.

Granger, C.W., 1981. Some properties of time series data and their use in econometric model specification. Journal of econometrics, 16(1), pp.121-130.

Granger, C.W., Huangb, B.N. and Yang, C.W., 2000. A bivariate causality between stock prices and exchange rates: evidence from recent Asianflu. The Quarterly Review of Economics and Finance, 40(3), pp.337-354.

Gujarati. (2004). Basic econometrics. McGraw-Hill Companies, 4th edition.

Gujarati: (2004) Basic Econometrics, 4th edn., USA: The McGraw-Hill Companies.

Hacioglu, Ü. and Dincer, H. eds., 2013. Managerial Issues in Finance and Banking: A Strategic Approach to Competitiveness. Springer Science \& Business Media.

Harris, R.(1999).Using Co-integration Analysis in Econometric Modeling. London, Prentice hall.

Johansen, S., 1988. Statistical analysis of cointegration vectors. Journal of economic dynamics and control, 12(23), pp.231-254.

Johansen, S., 1991. Estimation and hypothesis testing of cointegration vectors in Gaussian vector autoregressive models. Econometrica: Journal of the Econometric Society, pp.1551-1580.

Johansen, S., 1995. Identifying restrictions of linear equations with applications to simultaneous equations and cointegration. Journal of econometrics, 69(1), pp.111-132.

Johnson, H.G., 1976. Elasticity, absorption, Keynesian multiplier, Keynesian policy, and monetary approaches to devaluation theory: a simple geometric exposition. The American economic review, 66(3), pp.448-452.

Kibret, H., 1994. Is the Ethiopian Birr Overvalued? A Preliminary Assesment and Policy Implication. The Ethiopian Economy: Problems of Adjustment.

Kidane, A., 1999. Real exchange rate price and agricultural supply response in Ethiopia: The case of perennial crops.

Lencho, B.D., 2013. The effect of exchange rate movement on trade balance in Ethiopia.

Magazzino, C., 2012. Wagner's Law and Augmented Wagner's Law in EU-27-A Time-Series Analysis on Stationarity, Cointegration and Causality.

Magee, S.P., 1973. Currency contracts, pass-through, and devaluation. Brookings Papers on Economic Activity, 1973(1), pp.303-325.

Ministry of Finance and Economic Development (MoFED), 2010. Growth and Transformation Plan 2010/11$2014 / 15$.

Morck, R., Yeung, B. and Yu, W., 2000. The information content of stock markets: why do emerging markets have synchronous stock price movements? Journal of financial economics, 58(1-2), pp.215-260.

Narayan, P. (2005). The Saving and Investment Nexus for China: Evidence from Co-integration Tests .Applied Economics, 37: 1979-1990

NBE (2018). Ethiopian national bank exchange rate, Available at: < https://www.nbe.gov.et/market/banksexchange.html(accessed on June, 2018).

Paul R. Krugman, Maurice Obstfeld and Marc J. Melitz (2012) International Economics THEORY \& POLICY, 9th edn., USA: Pearson Series in Economics.

Pesaran, H., Shin,Y.,and R. Smith (2001). Bounds Testing Approaches to the Analysis of Level Relationships. Journal of Applied Econometrics, 16(3):1924-1996.

Pesaran, H., Shin,Y.,and R. Smith (2001). Bounds Testing Approaches to the Analysis of Level Relationships. Journal of Applied Econometrics, 16(3):1924-1996.

Phillips, P.C. and Ouliaris, S., 1990. Asymptotic properties of residual based tests for cointegration. Econometrica: Journal of the Econometric Society, pp.165-193.

Phillips, P.C., 1986. Understanding spurious regressions in econometrics. Journal of econometrics, 33(3), pp.311340.

Phillips, P.C., 1987. Time series regression with a unit root. Econometrica: Journal of the Econometric Society, pp.277-301.

Piontkivsky, R., 1999. exchange rate effects on the current account (would the devaluation improve the ukrainian 
current account) (Doctoral dissertation, MA thesis, Economic Education and Research Consortium, University of Ukraine, Ukraine).

Salvatore, D., 2003. International trade and economic development. Istituzioni e sviluppo economico, (2), pp.1000-1021.

Setzer, R., 2006. The Politics of Exchange Rates in Developing Countries: Political Cycles and Domestic Institutions. Springer Science \& Business Media.

Sims, C.A.,1980. Macroeconomics and reality. Econometrica: Journal of the Econometric Society,pp.1-48.

Stock, J.H. and Watson, M.W., 1988. Testing for common trends. Journal of the American statistical Association, 83(404), pp.109 